\title{
The Impact of Tourism on the Economy and Community Welfare in Labuan Bajo Area, Indonesia
}

\author{
Edhie Baskoro Yudhoyono ${ }^{1 *}$, Hermanto Siregar ${ }^{2}$, Noer Azam Achsani $^{3}$, Tony Irawan ${ }^{2}$ \\ ${ }^{1}$ Management and Business Study Program, IPB University, Bogor 16680, Indonesia \\ ${ }^{2}$ Faculty of Economics and Management, IPB University, Bogor 16680, Indonesia \\ ${ }^{3}$ School of Business, IPB University, Bogor 16680, Indonesia
}

Corresponding Author Email: edhiebaskoroyudhoyono80@gmail.com

https://doi.org/10.18280/ijsdp.160219

Received: 27 January 2021

Accepted: 28 March 2021

\section{Keywords:}

tourism, economy, community welfare, Labuan Bajo

\begin{abstract}
This study aims to analyze the impact of tourism on the economy and people's welfare in the Labuan Bajo area. This research was quantitative research with primary and secondary data. The data analysis method used was multiple linear regression analysis with the first structural equation related to the community's welfare (business actors) and the second related to macroeconomic indicators. The research was conducted through a survey of 221 respondents and collecting quarterly data on financial reports. The results showed that the average level of income of business actors who opened a business in tourist locations was higher than those who opened businesses outside tourist sites. The variables of the average length of stay, inflation, and investment significantly affected Regional Original Income in West Manggarai. A business's characteristics were the main determinants of people's welfare and not the perpetrators' characteristics. These results contributed to developing an integrated tourism model that is relevant to the tourist area of Labuan Bajo. The conclusion was that tourism impacted the West Manggarai Regency's economy, including increased local revenue, employment, and gross domestic income.
\end{abstract}

\section{INTRODUCTION}

Tourism plays a role in a country's economy. This role is reflected in foreign exchange earnings, absorption of investment, tax revenue, creation of new jobs, and reduced inequality and poverty [1]. In the Indonesian context, the fundamental role of tourism in the economy can be seen by forming the national Gross Domestic Product (GDP). It has continued to increase over the last five years. The tourism sector's contribution to the Indonesian economy is also reflected in its foreign exchange earnings. It has consistently increased from USD 10.8 billion in 2015 to USD 17.6 billion in 2019, based on the Ministry of Tourism data. Meanwhile, in terms of employment, the tourism sector has created 1.6 million new jobs in the last five years.

The tourism sector's development has looked quite good in recent years. Unfortunately, the Indonesian tourism sector's performance is still relatively lagging behind other countries in the world. In 2019, Indonesia only occupied the $27^{\text {th }}$ position globally regarding foreign exchange earnings in the tourism sector. This ranking is far from several countries in Southeast Asia, such as Thailand, Malaysia, and Singapore. Also, Indonesia is still ranked 40 in the world in 2019 based on the value of the Tour and Tourism Competitiveness Index (TTCI).

Indonesia still has to improve the competitiveness of tourism on an international scale. Indonesia's potential for tourism is enormous. It was considered by following the fact that Indonesia has more than 17,000 islands, 300 ethnic groups, 742 languages, 13 cultural heritage sites, 51 national parks, and the $3^{\text {rd }}$ most extensive biodiversity in the world. One of the world's cultural heritage sites in Indonesia and one of the seven new natural wonders of the world is the Komodo National Park.

Komodo National Park is one of the international tourist destinations, precisely located in Labuan Bajo Village, West Manggarai Regency, East Nusa Tenggara Province. The tourism potential of Labuan Bajo can be seen from the dynamics of tourist visits in the area in recent years. During the last five years, data from the Central Statistics Agency (BPS) of East Nusa Tenggara Province recorded the number of arrivals and departures at Komodo Airport continued to increase during the 2015-2019 period significantly. Besides, the occupancy rate of star-rated hotel rooms in West Manggarai Regency has also increased, which in July 2020 was $27.15 \%$ to $29.11 \%$ in August 2020 .

Interestingly, although the tourist attraction of Labuan Bajo is increasing, the economy and welfare of the Labuan Bajo people have not improved. West Manggarai Regency BPS data shows that in 2019, the people's welfare in West Manggarai is still low, with the poverty rate reaching $18.01 \%$. The Human Development Index (HDI) in West Manggarai Regency is still relatively low (63.50). Although the Gross Regional Domestic Product (GRDP) of West Manggarai Regency has consistently increased every year, tourism contribution to economic growth is still low. It is reflected in the accommodation and food and drink provider subsector's contribution, which only amounted to $0.8 \%$ in 2019 (IDR 27.7 billion). Besides, the tourism sector can also absorb $4.7 \%$ of the workforce in West Manggarai in 2019. The insignificant impact of tourism on the economy and 
community welfare in Labuan Bajo shows that optimal Labuan Bajo tourism development efforts still need to be formulated. The impact of tourism development should not only be felt by the government/state (in terms of foreign exchange earnings and national income) and community groups or certain business actors but also beneficial to the regional economy and community welfare (both in and around tourist areas) $[2,3]$.

Therefore, the researcher felt the need to analyze the impact of tourism on the Labuan Bajo people's economy and welfare. This study will contribute as a reference for formulating the right tourism model in tourism development in Labuan Bajo, which is economically oriented and integrated, inclusive, and sustainable.

\section{METHOD}

The research was conducted from December 2019 to December 2020 and was located in the Labuan Bajo Village, West Manggarai Regency, East Nusa Tenggara Province, Indonesia. This research was quantitative. The data collected included primary data, namely a survey of 221 tourism business actors in the tourist area of Labuan Bajo, and secondary data in the form of quarterly time series data for the last ten years. The survey respondents' selection was carried out using a non-probabilistic sampling method, which refers to the criteria for representing the respondents' diversity, respondents' composition, and the coverage of observed respondents. The secondary data contain the macro-economic data taken from 2010-2019. It was then interpolated into quarterly data, so that there are 40 observations. The data is obtained from related institutions, like Indonesian Statistical Bureau (BPS), Indonesian Tourism Department, Indonesian Finance Ministry, etc. the connection between primary and secondary data collected can be seen as two side of the same mirror.

The specification of the econometric model used was classified into two types based on the data structure used. The first econometric model used cross-section data at the microlevel to answer how tourism's impact on the business community's welfare is measured by income level. Meanwhile, the factors affecting the level of income of business actors were classified into five groups, namely the demographic characteristics of the respondents (age, gender, and education level), the characteristics of the respondent's business (length of business, type of business, business scale, business location, location distance. business from home, number of employees, and time spent working), financing characteristics (amount of initial capital and source of capital), technology represented by the adoption of technology use in running a business, and the involvement of respondents in tourism organizations. The data analysis method used for this econometric model was a multiple linear regression analysis.

Eq. (1):

$$
\begin{array}{rl}
P P U_{i}=\alpha_{0}+\alpha_{1} & U S I A_{i}+\alpha_{2} J K_{i}+\alpha_{3} T P E N D_{i} \\
& +\alpha_{4} L U_{i}+\alpha_{5} D U_{i}+\alpha_{6} D S U_{i} \\
& +\alpha_{7} D L U_{i}+\alpha_{8} D I S T_{i}+\alpha_{9} J K A R_{i} \\
& +\alpha_{10} W K E R J A_{i}+\alpha_{11} C_{A} P_{i} \\
& +\alpha_{12} \text { SCAP }_{i}+\alpha_{13} D T E K_{i} \\
& +\alpha_{14} \text { ORG }_{i}+\varepsilon
\end{array}
$$

Note:
- $\mathrm{PPU}=$ Income of Business Actors (Average Million IDR / Month)

- USIA = Age (Years)

- JK = Gender (1: Male; 0: Female)

- $\quad$ TPEND = Education Level (1: Completed Junior High School or below; 2: Graduated from High School; 3: Graduated from College)

- $\mathrm{LU}=$ Duration of Business (Year)

- $\mathrm{DJU}=$ Dummy of Business Type (1: Accommodation; 2: Transportation; 3: Services and Trade)

- DSU = Dummy of Business Scale (1: Medium and Large; 0: Micro and Small)

- DLU = Dummy of Business Location (1: Inside tourist sites; 0: Outside tourist sites)

- DIST = Distance from House to Tourist Location $(\mathrm{m} / \mathrm{km})$

- JKAR = Number of Employees (Person)

- $\quad$ WKERJA = Outline of Work Time (Hours per week)

- $\mathrm{CAP}=$ Amount of Initial Capital (Million IDR)

- SCAP = Source of Capital (1: Own; 2: Bank Loans; 3: Non-Banking Loans; 4: Others)

- DTEK = Dummy of Technology Adoption (1: Yes; 0: No)

- $\mathrm{ORG}=$ Dummy of participation in tourism organizations (1: Participate; 0: No)

- $\varepsilon=$ Error term

Meanwhile, the second econometric model was intended to determine the predicted impact of the tourism sector on the Labuan Bajo area's economy by taking West Manggarai Regency's scope. Therefore, the data used were regional macro-level data. The specification of this model was expressed in terms of four interrelated structural equations and two identity equations. The structural equation consists of Regional Original Income (Pendapatan Asli Daerah (PAD) in Indonesian), labor, Gross Regional Domestic Product (Pendapatan Domestik Regional Bruto (PDRB) - in Indonesian), and poverty. Meanwhile, the identity equation consists of total local government revenue and total regional government spending.

Eq. (2): Regional Original Income / Pendapatan Asli Daerah (PAD)

$$
\begin{gathered}
P A D_{t}=\beta_{10}+\beta_{11} J W T_{t}+\beta_{12} R L M_{t}+\beta_{13} I N F_{t} \\
+\beta_{14} I N V_{t}+\varepsilon_{1 t}
\end{gathered}
$$

Note:

- $\mathrm{PAD}=$ Regional Original Income / Pendapatan Asli Daerah (IDR. Billion)

- JWT = Total Number of Tourist Visits $(000$ People)

- $\mathrm{RLM}=$ Average Length of Stay for Travelers (days)

- $\quad$ INF = Inflation $(\%)$

- $\mathrm{INV}=$ Investment (IDR. Billion)

- $\varepsilon_{1} \quad=$ Error term

Eq. (3): Labor (TK)

$$
\begin{array}{rl}
T K_{t}=\beta_{20}+\beta_{21} J & W N_{t}+\beta_{22} R L M_{t}+\beta_{23} T P E N D_{t} \\
& +\beta_{24} E X P_{t}+\beta_{25} D A K_{t} \\
& +\beta_{26} I N V_{t}+\varepsilon_{2 t}
\end{array}
$$

Note: 
- $\mathrm{TK}=$ Number of Workers (000 people)

- $\mathrm{JWN}=$ Number of Indonesian Tourist Visit $(000$ People)

- RLM = Average Length of Stay for Travelers (Days)

- $\quad$ TPEND $=$ Average Years of Schooling (Years)

- $\quad$ INV = Investment (IDR. Billion)

- $\mathrm{EXP}=$ Total Local Government Expenditure (IDR. Billion)

- DAK = Special Allocation Fund (IDR. Billion)

- $\varepsilon_{2}=$ Error term

Eq. (4): Economy, Gross Regional Domestic Product / Pendapatan Domestik Regional Bruto (PDRB)

$$
\begin{array}{r}
P D R B_{t}=\beta_{30}+\beta_{31} I N V_{t}+\beta_{32} P A D_{t}+\beta_{33} T K_{t} \\
+\beta_{34} E X P_{t}+\beta_{35} D K P_{t}+\varepsilon_{3 t}
\end{array}
$$

Note:

- $\quad$ INV = Investment (IDR. Billion)

- $\mathrm{PAD}=$ Regional Original Income $/$ Pendapatan Asli Daerah (IDR. Billion)

- $\mathrm{TK}=$ Labor $(000$ people)

- EXP = Total Local Government Expenditure (IDR. Billion)

- DKP = Tourism Policy Dummy (1: After priority destination policy ( $\geq 2016)$; 0: Others)

- $\varepsilon_{3}=$ Error term

Eq. (5): Poverty (Inclusivity)

$$
\begin{aligned}
P O V_{t}=\beta_{41}+\beta_{41} P D R B_{t}+\beta_{42} I N V_{t}+\beta_{43} I N F_{t} \\
+\beta_{44} T K_{t}+\beta_{45} E X P_{t}+\beta_{46} D K P_{t} \\
+\varepsilon_{4 t}
\end{aligned}
$$

Note:

- $\mathrm{POV}=$ poverty rate $(\%)$

- PDRB = Produk Domestik Regional Bruto / Gross Regional Domestic Product (IDR. Miliar)

- $\mathrm{INV}=$ Investment (IDR. Billion)

- INF = Inflation (\%)

- $\mathrm{TK}=$ Labor $(000$ people $)$

- EXP = Total Local Government Expenditure (IDR. Billion)

- DKP = Dummy of Tourism Policy (1: After priority destination policy $(\geq 2016)$; 0 : Others)

- $\varepsilon_{4} \quad=$ Error term

Eq. (6): Regional Revenue and Expenditure Budget / Anggaran Pendapatan dan Belanja Daerah (APBD)

$$
\begin{gathered}
R E V_{t}=P A D_{t}+D A K_{t}+R E V L_{t} \\
E X P_{t}=E X P T O U R_{t}+E X P L_{t}
\end{gathered}
$$

Note:

- REV = Total Local Government Revenues (IDR. Billion)

- $\mathrm{PAD}=$ Regional Original Income (IDR. Billion)

- DAK = Special Allocation Fund (IDR. Billion)

- REVL = Other income (IDR. Billion)

- $\operatorname{EXP}=$ Total Local Government Expenditure (IDR. Billion)

- EXPTOUR = Shopping for Tourism and Culture (IDR. Billion)

- EXPL $=$ Other Expenditures (IDR. Billion)

\section{RESULTS \& DISCUSSION}

3.1 Analysis of tourism impact prediction on community welfare (business actors): Econometric analysis at the micro level

Table 1 presents the estimated impact of tourism on the income of business actors at the micro-level, as represented in Eq. (1). In this study, Eq. (1) estimated for 3 (three) different cases, such as (i) using all observations (Column a), (ii) involving only the observations of respondents with micro and small-scale enterprises (Column b), and (iii) only involves the observation of respondents engaged in the accommodation business (Column c). In the second case, the model was estimated only for micro and small business actors because most respondents observed were business actors at the micro and small level. Likewise, the model was estimated separately in the third case because most of the respondents observed were respondents engaged in the accommodation business (hotels and restaurants). The difference in estimation approaches was expected to provide variations in the estimation results based on the respondent's business characteristics and test each coefficient of estimation producer's robustness.

In general, the estimation results generated for each case were quite good. They can be seen from each case's F-test results, significant at the $1 \%$ significance level. These results explained that the independent variables used in the model for each case significantly affected the dependent variable (business actor's income). Besides, the estimation results of each case produced the coefficient of determination (R-Square) between 0.3904-0.7309 (Table 1). This value explained that about $39.04-73.09 \%$ of the diversity of business actors' income could be explained by the independent variables used in the model.

Meanwhile, if analyzed individually, not every independent variable used in the model had a significant effect on the business actor's income. It can be seen that the variables with a significant effect on differences in income of business actors were the age of the business actor, the business actor's education level dummy, the length of business, the business type dummy, the business scale dummy, the business location dummy, the number of employees, the capital source dummy, the technology adoption dummy, and business actor participation dummy in tourism organizations. In general, the variables' estimated coefficients with a significant effect were following theoretical expectations. Likewise, the coefficients that were significant in some cases had the same estimation sign. It shows that the estimation coefficient generated was robust when estimated with a different number of observations based on the respondent's business characteristics.

The coefficient of age estimation of business actors was positive and significant at the significant level of $10 \%$ in the second case. These results indicated a tendency for micro and small-scale business actors with a higher age level to have a higher income level on average. Meanwhile, the dummy estimation results for the level of education for business actors who graduated from tertiary education were positive and significant (at a significant level of 1-10\%) for all cases. It explained that, in general, business actors in the Labuan Bajo area who took tertiary education tended to have higher levels of income than those who graduate from high school and junior high school education and below. This fact was understandable because education was near related to the 
competence of business actors in general. Then, business actors in the Labuan Bajo area with a higher education level tended to have a high-income level. These results were generally in line with empirical studies [4-7] who found that the education level of actors played a significant role in improving business performance and profits. However, these results were not in line with [8], who reveals that education does not significantly affect business actors' income.

Meanwhile, the dummy coefficient estimates of business types for business actors operating in the service and trade sector was found to be negative and significant at the $5 \%$ of the significant level in the first case. This result explains that the average income level of business actors engaged in services and trade in the Labuan Bajo area was lower than that of business actors engaged in accommodation and transportation. Likewise, the business scale's dummy estimation was positive and significant at the $1 \%$ real level for the first and third cases. This fact explained that tourism businesses in the Labuan Bajo area with large-medium scale businesses on average had a higher level of business income than micro and small-scale businesses. This result was understandable because business actors with medium and large scales have an enormous business scope, so their business income will generally be higher than those of micro and small scale.

Table 1 also shows that the dummy coefficient estimation of business locations was positive and significant at the $5 \%$ significant level for all cases. This result explained that business actors' average income level opening a business inside tourist locations was higher than those opening outside tourist sites. This fact indicated that the existence of tourism objects could boost the income level of business actors. The business actors located in tourism locations tended to have a higher income level than business actors outside the area. This result was understandable because locations within tourism objects tended to have more significant market potential, with many tourists visiting or being in these locations. In general, location and duration of business affect positively and significantly on business growth in the tourism sector [9-11].

Furthermore, estimating the number of employees was also negative and significant at the 5\% significant level in the third case. These results explained a tendency for business actors to engage in accommodation and have more employees, having lower operating income levels. This result was under the theoretical expectation that business actors with more employees would positively impact higher operating costs, which reduces the level of business income. The estimation results also showed that the amount of initial capital had a positive effect on the operating income level. However, it was only significant in the second case. They indicated that micro and small-scale business actors in the Labuan Bajo area with a higher initial capital level tended to have a higher level of business income. A positive and significant relationship between credit and capital on business actors' income [11-14].

Table 1. The estimation results of the tourism impact prediction model at the micro-level

\begin{tabular}{|c|c|c|c|c|c|c|}
\hline \multirow{2}{*}{ Independent Variable } & \multicolumn{5}{|c|}{ Estimation Coefficient } & \\
\hline & (a) & & (b) & & (c) & \\
\hline Intercept & 1.880 & & 0.313 & & 2.708 & \\
\hline Age & 0.020 & & 0.036 & $*$ & 0.010 & \\
\hline Dummy of Gender $(1=$ Male; $0=$ Female $)$ & -0.094 & & 0.178 & & 0.223 & \\
\hline \multicolumn{7}{|c|}{ Dummy of Education Level $($ Baseline $=$ Completed $<$ SMP) } \\
\hline Graduated from high school & -0.329 & & 0.118 & & -0.254 & \\
\hline Graduated from College & 1.661 & $*$ & 1.366 & $*$ & 2.691 & $* * *$ \\
\hline Duration of business & 0.109 & & 0.284 & $* * *$ & 0.062 & \\
\hline \multicolumn{7}{|c|}{ Dummy of Business Type (Baseline $=$ Accommodation $)$} \\
\hline Transportation & 0.018 & & -0.111 & & - & \\
\hline Trade Services & -1.594 & $* *$ & -0.799 & & - & \\
\hline $\begin{array}{c}\text { Dummy of Business Scale }(1=\text { Medium and Large; } 0=\text { Micro } \\
\text { and Small })\end{array}$ & 7.940 & $* * *$ & - & & 7.268 & $* * *$ \\
\hline $\begin{array}{c}\text { Dummy of Business Location }(1=\text { Inside Tourist Locations; } 0 \\
=\text { Outside })\end{array}$ & 3.002 & $* * *$ & 2.835 & $* * *$ & 2.876 & $* * *$ \\
\hline Distance from Residence to Tourist Location & $<0.001$ & & $<0.001$ & & $<0.001$ & \\
\hline Number of employees & -0.142 & & -0.031 & & -0.375 & ** \\
\hline Working Time & -0.053 & & -0.049 & & -0.046 & \\
\hline Initial Capital Amount & 0.012 & & 0.027 & $*$ & 0.024 & \\
\hline \multicolumn{7}{|c|}{ Dummy of Capital Source (Baseline $=$ Own) } \\
\hline Bank Loans & 7.301 & $* *$ & -1.253 & & -5.959 & \\
\hline Non-Bank Loans & -1.727 & & 6.272 & $* *$ & - & \\
\hline Others & 0.191 & & 0.157 & & 0.131 & \\
\hline $\begin{array}{c}\text { Dummy of Technology Adoption }(1=\text { Adopt; } 0=\text { Not } \\
\text { Adopted })\end{array}$ & 2.243 & $* * *$ & 0.684 & & 3.251 & $* * *$ \\
\hline $\begin{array}{c}\text { Dummy of Tourism Organization Participation }(1= \\
\text { Participated; } 0=\text { Not Participated })\end{array}$ & 2.171 & $* * *$ & 1.274 & $*$ & 3.487 & $* * *$ \\
\hline Number of Observations & 221 & & 184 & & 155 & \\
\hline F-Stat (P-value) & $\begin{array}{c}21.15 \\
(<0.001)\end{array}$ & $* * *$ & $\begin{array}{c}6.25 \\
(<0.001)\end{array}$ & $* * *$ & $\begin{array}{c}25.17 \\
(<0.001)\end{array}$ & $* * *$ \\
\hline R-Square & 0.6534 & & 0.3904 & & 0.7309 & \\
\hline AIC & 1237.4 & & 915.2 & & 845.2 & \\
\hline $\mathrm{BIC}$ & 1302.0 & & 973.1 & & 893.9 & \\
\hline
\end{tabular}

Note: ***: Significant at $1 \%$ significance level, **: Significant at $5 \%$ significance level, ${ }^{*}$ : Significant at $10 \%$ significance level 
It was found that the estimation results of the dummy sources of capital for business actors had varied impacts on operating income in each case. In the first case, the bank loan category's capital source dummy was positively and significantly at the $5 \%$ significance. The results of this estimation explain that, on average, the income of business actors using loan capital from banks was higher than those of business actors using other sources of capital. However, in the second case, micro and small-scale respondents, the modeling source that positively and significantly impacted business actors' increase was non-bank loans. These results explained that micro and small businesses that obtain non-banking loans on average had a higher business income level. This finding was interesting because, in general, it explained that business actors who can access loans, either through formal institutions such as banks or non-banks, had a higher average level of opinion. This fact indicated that access to financial institutions could boost the business performance of tourism business actors. These results are generally in line with empirical studies that increasing accessibility to financial institutions, in general, can improve the performance of small and medium enterprises [15-17].

Meanwhile, the Dummy estimation results of technology adoption were positive and significant at the $1 \%$ significance level in all cases, except the second case. The results of this estimate explained that, on average, the income of business actors who adopt or utilize technology assistance - such as the internet and social media - was higher than those who do not utilize this technology. In another sense, the use of technology for business generally plays a significant role in improving business actors' financial performance. The use of the right technology is one of the factors that has a significant effect on the income of business actors, minimal and medium enterprises [18-22]. Finally, the dummy estimate results for the participation of business actors in tourism organizations were positive and significant at the $1 \%$ significant level in all cases. This estimation result explained that, on average, business actors who join tourism organizations were higher than business actors who do not join tourism organizations. These results indicated that business actors' participation in tourism organizations could substantially improve business actors' financial performance.

\subsection{Simultaneous equation system analysis: Econometric model at macro level results of the analysis of econometric model parameter estimates}

The estimation of structural equation parameters from the simultaneous equation model used in this study is presented in Box 1. In general, the Two-Stage Least Squares (2SLS) method used showed quite good estimation results. The result of parameter estimation from the model gave a relatively large determination coefficient (R2) for each structural equation. Box 1 shows the coefficient of determination generated by all structural equations were ranging from 41.00 - 98.03 percent. It indicated that the explanatory variables used in the model could explain each endogenous variable's diversity in each equation exceptionally well.

In each structural equation, the explanatory variables were found to affect the endogenous variables together significantly. It was indicated by the F (Wald) statistic is a relatively large value, which ranged from 9.78 to 275.74. Besides, the endogenous variables in each structural equation were generally influenced significantly by most of the explanatory variables individually at the significant level $(\alpha)$, which varied from 0.01 to 0.05 (Box 1). However, based on the estimation results, it can be seen that the structural equation had autocorrelation and heteroscedasticity problems. Although these equations experience symptoms of autocorrelation and heteroscedasticity as shown by the results of the DurbinWatson test (DW) and White's test (Box 1), however, as stated by [23], autocorrelation and heteroscedasticity only affect the efficiency of the estimates, while the estimation parameters remain unbiased and consistent.

\section{(1) PAD Equation Estimations}

Based on Table 2, it can be seen that the variables of an average length of stay, inflation, and investment significantly affected the formation of Regional Original Income (PAD) in West Manggarai. Tourism performance can play a role in local government revenue $[24,25]$. Hotel room occupancy or length of stay has an impact on $P A D$ [26]. However, these findings contradict the research results of $[26,27]$, which revealed that the number of tourists visits significantly impacted $P A D$ performance. Meanwhile, the results of this study, which indicate that inflation and investment have a significant effect on $P A D$ [28-32].

Box 1. Estimation results of simultaneous model structure equation parameters

$$
\begin{aligned}
& \mathrm{PAD}=-32.63+0.00015^{*} \mathrm{JWT}+20.57^{*} \mathrm{RLM}-1.03^{*} \mathrm{INF}+0.073^{*} \mathrm{INV} \\
& {\left[\begin{array}{lllll}
0.026] & {[0.316]} & {[0.027]} & {[0.0025]} & {[0.0033]}
\end{array}\right.} \\
& \mathrm{F}(\text { Wald }) \text {-Stat }=9.78[0.0018] ; \mathrm{R}^{2}=0.9365 ; \mathrm{DW}=0.41 ; \text { White }=37.21 \\
& \mathrm{TK}=61.83+0.00006^{*} \mathrm{JWN}+0.699^{*} \mathrm{RLM}+4.576^{*} \mathrm{TPEND}-0.152^{*} \mathrm{EXP}+0.499^{*} \mathrm{DAK}+0.099^{*} \mathrm{INV} \\
& {[0.257][0.702] \quad[<0.0001] \quad[0.610] \quad[0.0004] \quad[<0.0001] \quad[<0.0001]} \\
& \mathrm{F}(\text { Wald }) \text {-Stat }=122.829[<0.0001] ; \mathrm{R}^{2}=0.5952 ; \mathrm{DW}=0.36 ; \text { White }=39.94 \\
& \mathrm{PDRB}=248.307+0.559^{*} \mathrm{INV}+0.454^{*} \mathrm{PAD}+0.499^{*} \mathrm{TK}+0.088^{*} \mathrm{EXP}+0.049^{*} \mathrm{DKP} \text {; } \\
& {[<0.0001] \quad[<0.0001] \quad[0.473] \quad[<0.0001] \quad[0.636] \quad[<0.0001]} \\
& \mathrm{F}(\text { Wald }) \text {-Stat }=20.91[<0.0001] ; \mathrm{R}^{2}=0.9803 ; \mathrm{DW}=0.22 ; \text { White }=35.24 \\
& \mathrm{POV}=58.250-0.108^{*} \mathrm{PDRB}-0.00021 \mathrm{INV}+0.240^{*} \mathrm{INF}-0.0928^{*} \mathrm{TK}+0.100^{*} \mathrm{EXP}-0.110^{*} \mathrm{DKP} \text {; } \\
& {[<0.0001][<0.0001][0.989][0.047] \quad[0.636] \quad[<0.0001] \quad[<0.0001]} \\
& \mathrm{F}(\text { Wald })-\text { Stat }=275.74[<0.0001] ; \mathrm{R}^{2}=0.4100 ; \mathrm{DW}=0.36 ; \text { White }=39.31
\end{aligned}
$$


(2) Estimation of the Labor Equation

Based on Table 3, it can be seen that the variables of the average length of stay, local government spending, special allocation funds, and investment had a significant effect on labor in West Manggarai. The tourism sector represented by domestic tourist visits can encourage the absorption of labor in an area [33, 34]. Hotel occupancy rates positively and significantly affect employment [35]. Meanwhile, the level of education does not have a significant effect on labor absorption. It found that education level plays a vital role in increasing employment opportunities and making labor market conditions better. Even so, the results of this study regarding the significant role of investment in employment [36-38]. Also, regional government spending in regional government spending and special allocation funds/dana alokasi khusus (DAK) plays a vital role in employment and reducing unemployment in the regions $[39,40]$.

(3) Estimation Results of the Gross Regional Domestic Product (GRDP) / Produk Domestik Regional Bruto (PDRB) Equation

Based on the Table 4, it can be seen that the investment, labor, and tourism policy dummy variables had a significant effect on the formation of GRDP/PDRB in West Manggarai. Investment and government spending are among the primary formers of a country's Gross Domestic Product (GDP) [41]. In this context, investment and government spending are, of course, also the main components in the formation of GRDP for a region. The results of this study indicate that there was a significant effect of labor on GRDP. Population growth and labor force growth are traditionally considered positive factors that spur economic growth $[42,43]$. A larger number of workers means a larger size of the domestic market. Investment in the form of foreign and domestic investment as well as labor has a positive impact on GRDP [44-47].

\section{(4) Poverty Level (POV) Estimation}

Based on the Table 5, it can be seen that the variables of GRDP, inflation, labor, local government spending, and the tourism policy dummy had a significant effect on the poverty level in West Manggarai. An improving economy and continuous investment activities carried out by the community can increase economic activity, employment opportunities, and national income [48]. It, in turn, will increase the welfare of society and reduce poverty. Furthermore, labor is also considered to be linked to unemployment and poverty. Here, the low labor absorption in a region will impact increasing the unemployment rate in that region. High unemployment in a region indicates a low economic capacity, leading to an increase in the region's poverty rate. An economic downturn and rising unemployment rates can significantly increase poverty $[49,50]$. The inflation rate, weakening economic growth, and unemployment rates will significantly increase the poverty rate [49]. Government spending is an important instrument to reduce poverty in a region [51-53].

Table 2. Estimation results of $P A D$ equation parameters

\begin{tabular}{cccccc}
\hline Variable & Estimation Coefficient & Standard Error & t-Stat & P-Value & Sig. Level \\
\hline Intercept & -32.634 & 14.0495 & -2.32 & 0.0261 & $* *$ \\
Number of Tourists (JWT) & 0.00015 & $<0.001$ & 1.02 & 0.3155 & \\
Average Length of Stay (RLM) & 20.569 & 8.9499 & 2.30 & 0.0276 & $* *$ \\
Inflation (INF) & -1.030 & 0.3159 & -3.26 & 0.0025 & $* * *$ \\
Investment (INV) & 0.073 & 0.0232 & 3.15 & 0.0033 & $* * *$ \\
F(Wald)-Stat = 9.78 [0.0018]; R2 = 0.9365; DW=0.41; White = 37.21 & \\
\hline Note: **: Significant at 5\% significance level, ***: Significant at 1\% significance level
\end{tabular}

Table 3. Results of estimating parameters for the labor equation

\begin{tabular}{cccccc}
\hline Variable & Estimation Coefficient & Standard Error & t-Stat & P-Value & Sig. Level \\
\hline Intercept & 61.828 & 53.693 & 1.15 & 0.2569 & \\
Number of Travelers (JWN) & 0.00006 & $<0.001$ & 0.39 & 0.7024 & $* * *$ \\
Average Length of Stay (RLM) & 0.699 & $<0.001$ & 4911 & $<0.0001$ & $* * 1$ \\
Average Length of Schooling (TPEND) & 4.576 & 8.894 & 0.51 & 0.6100 & $* * *$ \\
Local Government Expenditure (EXP) & -0.152 & 0.039 & -3.90 & 0.0004 & $* * *$ \\
Special Allocation Fund (DAK) & 0.499 & $<0.001$ & 3508 & $<0.0001$ & $* * *$ \\
Investment (INV) & 0.099 & $<0.001$ & 701 & $<0.0001$ & \\
F(Wald)-Stat = 122.829 [<0.0001]; R2 = 0.5952; DW=0.36; White = 39.94 & & &
\end{tabular}

Table 4. Results of estimating parameters for the GRDP / PDRB equation

\begin{tabular}{cccccc}
\hline Variable & Estimation Coefficient & Standard Error & t-Stat & P-Value & Sig. Level \\
\hline Intercept & 248.307 & 8.352 & 29.73 & $<.0001$ & $* * *$ \\
Investment (INV) & 0.559 & 0.111 & 5.02 & $<.0001$ & $* * *$ \\
Regional Original Income (PAD) & 0.454 & 0.626 & 0.72 & 0.4734 & \\
Labor (TK) & 0.499 & $<0.001$ & 3508 & $<.0001$ & $* * *$ \\
Local Government Expenditure (EXP) & 0.088 & 0.184 & 0.48 & 0.6358 & $* * *$ \\
Tourism Policy Dummy (DKP) & 0.049 & $<0.001$ & 350 & $<.0001$ & $* * *$ \\
F(Wald)-Stat $=20.91[<0.0001] ; \mathrm{R} 2=0.9803 ; \mathrm{DW}=0.22 ;$ White $=35.24$ & &
\end{tabular}

Note: **: Significant at $5 \%$ significance level, ${ }^{* * *}$ : Significant at $1 \%$ significance level 
Table 5. Results of estimating parameters for the poverty level equation

\begin{tabular}{cccccc}
\hline Variable & Estimated Coefficient & Standard Error & t-Stat & P-Value & Sig. Level \\
\hline Intercept & 58.25027 & 3.5156 & 16.57 & $<.0001$ & $* * *$ \\
Gross Domestic Product (GRDP/PDRB) & -0.10753 & 0.0156 & -6.91 & $<.0001$ & $* * *$ \\
Investment (INV) & -0.00021 & 0.0149 & -0.01 & 0.9887 & $* *$ \\
Inflation (INF) & 0.240058 & 0.1165 & 2.06 & 0.0468 & $* *$ \\
Labor (TK) & -0.09247 & 0.0156 & -5.94 & $<.0001$ & $* *$ \\
Local Government Expenditure (EXP) & 0.100429 & 0.0149 & 6.73 & $<.0001$ & $* * *$ \\
Tourism Policy Dummy (DKP) & -0.11043 & 0.0149 & -7.40 & $<.0001$ & $* * *$ \\
F(Wald)-Stat $=275.74[<0.0001] ; \mathrm{R} 2=0.4100 ; \mathrm{DW}=0.36$; White $=39.31$ & & \\
\hline
\end{tabular}

Note: **: Significant at 5\% significance level, ***: Significant at $1 \%$ significance level

Table 6. Results of the model validation statistics criteria of fit

\begin{tabular}{|c|c|c|c|c|c|}
\hline $\begin{array}{l}\text { Endogen } \\
\text { Variable }\end{array}$ & Explanation & $\begin{array}{c}\text { Mean Percentage Error } \\
(\%)\end{array}$ & $\begin{array}{l}\text { Mean Absolute } \\
\text { Error }\end{array}$ & $\begin{array}{l}\text { Mean Absolute Percentage } \\
\text { Error }\end{array}$ & $\begin{array}{c}\text { U- } \\
\text { Theil }\end{array}$ \\
\hline PAD & Regional original income & -0.9757 & 2.3418 & 21.1260 & 0.0717 \\
\hline TK & Labor & 0.1722 & 4.7489 & 4.4431 & 0.0275 \\
\hline PDRB /GDRB & Gross domestic product & 0.0121 & 5.3864 & 1.1789 & 0.0071 \\
\hline POV & Poverty Level & 0.0751 & 0.8121 & 4.2705 & 0.0288 \\
\hline
\end{tabular}

\subsection{Model validation}

The simulation was used to analyze the impact of changes from various scenarios, especially scenarios related to the tourism sector's policies on the economy and welfare of the West Manggarai Regency. The simulation was designed in five different scenarios (Table 6). Those were including:

(i) an increase in the role of tourism, as indicated by an increase in the number of tourist visits and the average length of stay of tourists, to the economy (represented by an increase in GRDP) and welfare (represented by a reduction in poverty levels); (ii) increased investment, Special Allocation Funds, and local government spending for tourism and culture on the economy and welfare. Before performing the simulation, the model validation was first carried out by calculating various statistical criteria of fit and U-Theil statistics to ensure that the resulting model was adequate for the simulation.

Several measurement criteria could be used to measure the statistics of fit. In this case, the criteria for Mean Percent Error (MPE), Mean Absolute Error (MAE), and Mean Absolute Percent Error (MAPE) would be used. These three approaches are used to measure the deviation between the estimated value and the actual value. Meanwhile, U-Theil statistics were used to evaluate the model's ability for simulation analysis. The UTheil statistical value, which was close to 0 , indicated that the model's ability to match each endogenous variable's actual value was quite good, so the model was suitable for simulation analysis. The results of the MPE, MAE, MAPE, and U-Theil statistics are presented in Table 6 . It can be seen that the resulting MPE, MAE, and MAPE values were relatively low. Most of the equations gave MAE values less than 10. Likewise, with MPE and MAPE values where most of the equations had MAPE values below 10 percent. In general, this explained that all equations provide an estimated average (mean) relatively close to the actual mean value. The same thing was shown by the U-Theil statistical value, which was close to zero, or produced a value below 0.1 . The results of model validation or calibration generally indicated the model could or was feasible to be used to simulate various planned policy scenarios

\section{CONCLUSIONS}

This study revealed that the business's characteristics and conditions were the main determinants of the welfare of the Labuan Bajo people compared to business actors' characteristics. Type of business, business scale, source of capital, technology adoption, and even the participation of business actors in tourism organizations positively impacted business actors' income. This result implied that it does not matter the business actor's background, but how the business was managed, which determines the tourism business's success. Thus, local and central governments as regulators could take intervention actions in tourism development through strengthening capital, support for technology adoption, and regulations related to tourism organizations.

This study also found that tourism had an impact on the economy of the West Manggarai Regency. The longer the tourists stay in Labuan, the greater the local income and labor absorption in West Manggarai Regency. The greater the employment, the higher the gross regional domestic income of West Manggarai. The amount of GRDP was also influenced by the local government's tourism policies of the West Manggarai Regency. Therefore, this research implied that an integrated tourism model needs to be formulated to develop the tourism potential of Labuan Bajo, which was on the rise. Cooperation of all parties, starting from the local government and the community, was needed in realizing the success of this integrated tourism model.

\section{REFERENCES}

[1] Skerritt, D., Huybers, T. (2005). The effect of international tourism on economic development: An empirical analysis. Asia Pacific Journal of Tourism Research, 10(1): 23-43. https://doi.org/10.1080/1094166042000330209

[2] Pedrana, M. (2013). Local economic development policies and tourism: An approach to sustainability and culture. Regional Science Inquiry Journal, 5(1): 91-99.

[3] Wijijayanti, T., Agustina, Y., Winarno, A., Istanti, L.N., Dharma, B.A. (2020). Rural tourism: A local economic development. Australasian Accounting, Business and Finance Journal, 14(1): 5-13. https://doi.org/10.14453/aabfj.v14i1.2

[4] Amarteifio, E.N.A., Agbeblewu, S. (2017). Level of education, business experience and small and medium 
enterprise performance in the Accra Metropolis of Ghana. Int. J. of Multidisciplinary and Current Research, 5(1): 1460-1466.

[5] Chiliya, N., Roberts-Lombard, M. (2012). Impact of level of education and experience on profitability of small grocery shops in South Africa. International Journal of Business Management and Economic Research, 3(1): 462-470.

[6] Hasan, N.I. (2019). Faktor-Faktor yang Mempengaruhi Peningkatan Pendapatan Usaha Mikro (Studi Pada Nasabah BMT As-Salam). Jurnal Ilmiah Ekonomi Islam, 5(01): 73-80. https://doi.org/10.29040/jiei.v5i01.464

[7] Purnomo, D., Sudana, I.P., Mananda, I.G.S. (2016). Pengaruh Pendidikan dan Pelatihan Terhadap Kompetensi Serta Dampaknya pada Kinerja Pramuwisata Bali. Jurnal IPTA (Industri Perjalanan Wisata), 4(2): 51-57.

https://doi.org/10.24843/IPTA.2016.v04.i02.p11

[8] Nainggolan, R. (2016). Gender, tingkat pendidikan dan lama usaha sebagai determinan penghasilan UMKM Kota Surabaya. Kinerja, 20(1): 1-12, https://doi.org/10.24002/kinerja.v20i1.693

[9] Mwalo, A., Destaings, N. (2020). Determinants of sale response probability and tourism backward linkage with local micro and small enterprises of Kisumu CountyKenya. Journal of Tourism Management Research, 7(2): $122-131$

https://repository.maseno.ac.ke/handle/123456789/2749

[10] Putri, N.M.D.M., Jember, I.M. (2016). Pengaruh modal sendiri dan lokasi usaha terhadap pendapatan Usaha Mikro Kecil Menengah (UMKM) di Kabupaten Tabanan (modal pinjaman sebagai variabel intervening). Jurnal Ekonomi Kuantitatif Terapan, 9(2): 228-283. https://doi.org/10.24843/JEKT.2017.v09.i02.p07

[11] Setiaji, K., Fatuniah, A.L. (2018). Pengaruh modal, lama usaha dan lokasi terhadap pendapatan pedagang pasar pasca relokasi. Jurnal Pendidikan Ekonomi Dan Bisnis (JPEB), 6(1): 1-14. https://doi.org/10.21009/JPEB.006.1.1

[12] Asni, L., Indrawati, H., Trisnawati, F. (2017). Dampak Penerimaan Kredit terhadap Pendapatan Pedagang Kecil di Pasar Lima Puluh Kota Pekanbaru. Jurnal Online Mahasiswa (JOM) Bidang Keguruan dan Ilmu Pendidikan, 4(1): 1-11.

[13] Purnamayanti, N.W.A., Suwendra, I.W., Yulianthini, N.N., SE, M. (2014). Pengaruh pemberian kredit dan modal terhadap pendapatan UKM, E-Journal Bisma, 2(1): $1-19$.

[14] Utami, H.T. (2018). Pengaruh Pengetahuan Pemilik, Skala Usaha, dan Umur Usaha terhadap Keberhasilan Kinerja Usaha dengan Penggunaan Informasi Akuntansi Sebagai Variabel Moderasi. Jurnal Ekonomi Islam, 6(1).

[15] Chesang, I. (2017). Effects of access to credit on financial performance of Small and Medium Enterprises in Nairobi county (Doctoral dissertation, University of Nairobi). African Development Finance Journal, 2(1): 233-256. http://hdl.handle.net/11295/103021

[16] Giang, M.H., Trung, B.H., Yoshida, Y., Xuan, T.D., Que, M.T. (2019). The causal effect of access to finance on productivity of small and medium enterprises in Vietnam. Sustainability, 11(19): 5451. https://doi.org/10.3390/su11195451

[17] Sanistasya, P.A., Rahardjo, K., Iqbal, M. (2019). Pengaruh Literasi Keuangan dan Inklusi Keuangan
Terhadap Kinerja Usaha Kecil di Kalimantan Timur. Ekonomia, 14: 48-59.

[18] Dai, W. (2009). The impact of emerging technologies on small and medium enterprises (SMEs). Journal of Law and Governance,

4(4). https://doi.org/10.15209/jbsge.v4i4.171

[19] Durowoju, S.T. (2017). Impact of technological change on small and medium enterprises performance in Lagos state. Economic and Environmental Studies, 17(4(44)): 743-756.

[20] Hasanah, R.L., Kholifah, D.N., Alamsyah, D.P. (2020). Pengaruh modal, tingkat pendidikan dan teknologi terhadap pendapatan umkm di kabupaten purbalingga. Kinerja, 17(2): 305-313.

[21] Purnomo, M. (2011). Adopsi teknologi oleh usaha mikro, kecil dan menengah. JDM (Jurnal Dinamika Manajemen), 2(2): 109-117.

[22] Dewi, N.P.M., Utari, T. (2014). Pengaruh modal, tingkat pendidikan dan teknologi terhadap pendapatan usaha mikro kecil dan menengah (UMKM) di Kawasan Imam Bonjol Denpasar Barat. E-Jurnal Ekonomi Pembangunan Universitas Udayana, 3(12): 44496.

[23] Pindyck, R.S., Rubinfeld, D.L. (1992). Microeconomics, 2nd ed. New York: Toronto: New York: Macmillan; Maxwell Macmillan Canada; Maxwell Macmillan International.

[24] Mardianis, M., Syartika, H. (2018). Kontribusi Sektor Pariwisata terhadap Pendapatan Asli Daerah (PAD) di Kabupaten Kerinci [The Contribution of Tourism Sector to Local Revenue in Kerinci Regency]. Jurnal Ekonomi \& Kebijakan Publik, 9(1): 53-65. https://doi.org/10.22212/jekp.v9i1.972

[25] Wong, J.D. (1996). The impact of tourism on local government expenditures. Growth and Change, 27(3): 313-326. 2257.1996.tb00908.x

[26] Wahyuni, E.T., Susilo, S., Muljaningsih, S. (2018). Regional economics: How does tourism influence regional revenue of Malang Raya? Journal of Indonesian Tourism and Development Studies, 6(2): 93-102.

[27] Kapang, S., Rorong, I.P., Maramis, M.T.B. (2019). Analisis pengaruh sektor pariwisata terhadap pendapatan asli daerah (pad) kota manado. Efisiensi, 19(04).

[28] Alavirad, A. (2003). The effect of inflation on government revenue and expenditure: The case of the Islamic Republic of Iran. Opec Review, 27(4): 331-341. https://doi.org/10.1111/j.0277-0180.2003.00074.x

[29] Batik, K. (2013). Analisis Pengaruh Investasi, PDRB, Jumlah Penduduk, Penerimaan Pembangunan, dan Inflasi terhadap Pendapatan Asli Daerah (PAD) di Kabupaten Lombok Barat. Jurnal Ekonomi Pembangunan, 11(1): 125-147. https://doi.org/10.22219/jep.v11i1.3735

[30] Greytak, D., Jump, B. (1977). Inflation and local government expenditures and revenues: Method and case studies. Public Finance Quarterly, 5(3): 275-302. https://doi.org/10.1177/109114217700500301

[31] Sartika, A.D., Madris, Syamsuddin. (2019). The effects of investment, government expenditures and labor productivity on local government financial performance. Global Scientific Journals, 7(7): 389-399.

[32] Weley, I.R., Kumenaung, A.G., Sumual, J.I. (2017). Analisis Pengaruh Inflasi dan Produk Domestik Regional Bruto (PDRB) terhadap Pendapatan Asli Daerah di Kota 
Manado. Jurnal Pembangunan Ekonomi Dan Keuangan Daerah, 18(6): 1-10. https://doi.org/10.35794/jpekd.16457.19.3.2017

[33] Oneţiu, A.N., Predonu, A.M. (2013). Economic and social efficiency of tourism. Procedía-Social and Behavioral Sciences, 92: 648-651. https://doi.org/10.1016/j.sbspro.2013.08.732

[34] Zandy, G.S., Ratwianingsih, L. (2019). The roles of the tourism sector in the labor absorption in the trade, restaurant, and accommodation sectors in Bali Province in 2013-2017. Journal of Applied Economics in Developing Countries, 4(1): 30-38.

[35] Windayani, I.A.R.S., Budhi, M.K.S. (2017). Pengaruh kunjungan wisatawan, tingkat hunian hotel, pengeluaran wisatawan terhadap penyerapan tenaga kerja dan pertumbuhan ekonomi di provinsi Bali. Jurnal Ekonomi Pembangunan, 6(2): 225-254.

[36] Baldwin, R.E. (1995). The effects of trade and foreign direct investment on employment and relative wages (No. w5037). National Bureau of Economic Research. Cambridge, MA, w5037, Feb. 1995. https://doi.org/10.3386/w5037

[37] Chortareas, G., Noikokyris, E. (2018). What is the Impact of Investment on Labor Income? World Bank, Washington, DC, 2018.

[38] Damayanti, N.L.E., Kartika, I.N. (2016). Pengaruh Kunjungan Wisatawan Asing Dan Investasi Terhadap Penyerapan Tenaga Kerja Serta Pertumbuhan Ekonomi. E-Jurnal EP Unud, 5(7): 882-900.

[39] Chodariyanti, L. (2016). Pengaruh alokasi anggaran pendapatan dan belanja daerah (apbd) terhadap penyerapan tenaga kerja di Kabupaten Jember, Jurnal EKBIS, 15(1): http://dx.doi.org/10.30736\%2Fekbis.v15i1.16

[40] Muammil, S. (2018). The effect of government expenditure and private investment on work opportunities and unemployment rate in Indonesia. Journal of Agricultural and Socio-Economic Sciences, 4(7): 92-100.

[41] Mankiw, N.G., Fortura, P., Manouchehri, S. (2002). Principles of macroeconomics. Toronto: Thomson/Nelson.

[42] Rosmalia, J., Iskandar, R., Fitriadi, F. (2014). Pengaruh investasi dan tenaga kerja terhadap produk domestik regional bruto (PDRB) dan pendapatan asli daerah (PAD) Kota Balikpapan, Ekonomika-Bisnis, 5(2): 159-172. https://doi.org/10.22219/jibe.v5i2.2266
[43] Todaro, M.P. (1995). Reflections on economic development: The selected essays of Michael P. Todaro. Brookfield, VT: Edward Elgar Publishing. Aldershot, Hants, England; Brookfield.

[44] Maisaroh, M., Risyanto, H. (2018). Pengaruh Investasi, Pengeluaran Pemerintah dan Tenaga Kerja terhadap PDRB Provinsi Banten. EkBis: Jurnal Ekonomi dan Bisnis, 1(2): 206-221. https://doi.org/10.14421/EkBis.2017.1.2.1049

[45] AZ, S.M., Pebrina, S. (2019). Analisis Pengaruh Tingkat Investasi, Pendapatan Asli Daerah dan Tenaga Kerja Terhadap PDRB Provinsi Jambi. Ekonomis: Journal of Economics and Business, 3(1): 36-43. http://dx.doi.org/10.33087/ekonomis.v3i1.54

[46] Putranto, R.D., Haribowo, P., Rini, N. (2016). Analisis pengaruh pendapatan asli daerah (pad), investasi, dan angkatan kerja terhadap pdrb provinsi jawa tengah (periode 1984-2013). JOBS (Jurnal Of Business Studies), 1(1): 81-94. http://dx.doi.org/10.32497/jobs.v1i1.638

[47] Salim, M. (2013). Pengaruh Investasi Dan Tenaga Kerja Terhadap PDRB Provinsi Papua. Future: Jurnal manajemen dan akuntansi, 1(1): 94-103.

[48] Sukirno, S. (1996). Pengantar teori ekonomi. Jakarta: PT RajaGrafindo Persada.

[49] Rumate, V.A., Engka, D.S. (2017). Pengaruh Tingkat Inflasi, Investasi, Pertumbuhan Ekonomi dan Tingkat Pengangguran Terhdap Tingkat Kemiskinan di Provinsi Sulawesi Utara. Jurnal Pembangunan Ekonomi Dan Keuangan Daerah, 18(6): 1-14. https://doi.org/10.35794/jpekd.16456.19.3.2017

[50] Wiguna, V.I., Sakti, R.K. (2012). Analisis Pengaruh PDRB, Pendidikan, dan Pengangguran Terhadap Kemiskinan di Provinsi Jawa Tengah Tahun 2005-2010. Jurnal Ilmiah Mahasiswa FEB, 1(2): 1-29.

[51] Alamanda, A. (2020). The effect of government expenditure on income inequality and poverty in Indonesia. Info Artha, 4(1): 1-11. http://dx.doi.org/10.31092/jia.v4i1.614

[52] Asghar, N., Hussain, Z., Rehman, H.U. (2012). The impact of government spending on poverty reduction: Evidence from Pakistan 1972 to 2008. African Journal of Business Management, 6(3): 845-853. https://doi.org/10.5897/AJBM11.922

[53] Omari, L.V., Muturi, W. (2016). The effect of government sectoral expenditure on poverty level in Kenya. Journal of Economics and Sustainable Development, 7(8): 219-242. 